\title{
Environmental Monitoring of Zoonotic Fungal Infection in Broiler Chickens: Novel Approach to Control using Nano-fungicide Composite
}

\author{
A. N. Mohammed* \& G. K. Abdel-Latef \\ Department of Hygiene, Zoonoses and Epidemiology, Faculty of Veterinary Medicine, Beni-Suef University, \\ Beni-Suef 62511, Egypt \\ Corresponding author: asmaa.mohamed2@vet.bsu.edu.eg \\ (Received 25-11-2020; Revised 10-01-2021; Accepted 02-02-2021)
}

\begin{abstract}
Control of fungal infections has not taken much attention compared to bacterial and viral pathogens inflicting significant economic losses to the poultry sectors as well as direct harms to human health due to their zoonotic implication. This study aimed to investigate the existence of fungal pathogens in broiler chicks dropping and their environment. As well, evaluate the efficiency of Terminator disinfectant (coco-benzyl-dimethyl ammonium chlorides and glutaraldehyde), nano copper oxide (CuO NPs), and Terminator/ nano copper oxide (Terminator/CuO NPs) on the fungal growth inhibition to control resistant fungus to antifungal agents. All samples $(n=320)$ were collected from chicks dropping, their environment (air, water, feeds, litter, drinkers, and feeders) as well, the attendant's hand swabs for isolation and identification of fungal pathogens. The susceptibility pattern of 65 strains of fungal isolates to antifungal agents, terminator disinfectant, and nanofungicide composites was determined by the disc diffusion assay and broth micro-dilution method. All isolates were highly resistant to voriconazole antifungal drugs, whilst Aspergillus fumigatus (A. fumigatus) was resistant (100\%) to fluconazole. Furthermore, the sensitivity of Aspergillus terreus ( $A$. terreus) and Penicillium corylophilum ( $P$. corylophilum) was $0.0 \%$ to fluconazole, and amphotericin-B. Whilst the antifungal activity of Terminator/CuO NPs against fungal pathogens proved its lethal effect $(100 \%)$ against all fungal isolates at $0.5 \mathrm{mg} / \mathrm{mL}$ compared to the efficiency of both Terminator at $1: 50$ and $\mathrm{CuO}$ NPs at $2.0 \mathrm{mg} / \mathrm{mL}$ was not exceeded $84.6 \%$ and $76.9 \%$, respectively against all fungal strains. In conclusion, nano-fungicide is a promising product for the prevention of fungal pathogens in broiler chickens and their environment. The control of zoonotic resistant fungus using novel nano-fungicide composite (Terminator/CuO NPs) at $0.5 \mathrm{mg} / \mathrm{mL}$ concentration was efficiently achieved compared to nano copper oxide at $2.0 \mathrm{mg} / \mathrm{mL}$.
\end{abstract}

Keywords: resistant fungus; chick's environment; nano-fungicide; antifungal agents; disinfectants

\section{INTRODUCTION}

Fungal diseases cause a direct/indirect infection through the production of mycotoxins that have potential economic losses. Some fungi are harmful to birds, and humans are being induced serious diseases (Hyde et al., 2018). In poultry farms, fungal diseases involve aspergillosis, candidiasis, favus, and cryptococcosis. Furthermore, the most important and impactful one was both aspergillosis, and candidiasis (Dhama et al., 2013; Girma et al., 2016). Besides, mycotoxins are one of the main causes that leading to produce immune suppression in birds, which makes them exposed to many viral and bacterial infections and subsequent cause economic losses to the poultry sectors (Asfaw \& Dawit, 2017).

Monitoring and/or the surveying of fungal infections in poultry flocks as well as following the prudent use of antifungal agents incorporate with strict biosecurity measures; sanitation, disinfection, and proper hygiene, are considered the essential elements in an effective prevention and control program (Dhama et al., 2013). Interestingly, the resistance of C. albicans to fluconazole and itraconazole drugs was observed while it was sensitive to amphotericin-B and ketoconazole at $0.5 \mu \mathrm{g} / \mathrm{mL}$ and $1 \mu \mathrm{g} / \mathrm{mL}$ (Zaidi et al., 2018). Quaternary ammonium surfactant compounds (QACs) are broadly used as antimicrobial and/or antifungal both alone and in combination with other chemical agents (Perinelli et al., 2019). Oppositely, there are various generations of quaternary compounds (Pernak et al., 2001), whereas benzalkonium chlorides are the primary generation obtained from quaternary salts with alkyl distributions. Moreover, compounds with long alkyl chains of $C_{12}$ were most effective against fungi and yeast. Meanwhile, the second-generation form was synthesized through aromatic ring substitution in alkyl-benzyl dimethyl ammonium chlorides (Brycki et al., 2011). In previous literature, Marek et al. (2015) found that alkyl chains of $\mathrm{C}_{14}$ and $\mathrm{C}_{16}$ analogs were more effective against yeast fungus, whilst $C_{16}$ was non-sensitive to filamentous fungi. On the other hand, none of the compounds evaluated had a higher level of sensitiv- 
ity compared to the benzalkonium $C_{12}$ analog. Using nanoparticles and/or nanomaterials as novel agents for micro-organisms growth inhibition has been developed due to the existing antimicrobial resistance (Eshed et al., 2012). Oppositely, the surrounding of Candida cells by exo-polymeric substance matrix can save the yeast cells against the antifungal agents. Among nanomaterial compounds, nanometals have been extensively used due to their being less toxic (Lara et al., 2015). Nano copper oxide ( $\mathrm{CuO} \mathrm{NP})$ has a range of potential physical properties, high surface areas, and unusual crystal morphologies. Copper element is essential for all living organisms. It could be easily mixed with polymers to provide the composites with unique physio-chemical characterizations and be used in biomedical applications (Chang et al., 2012). The present work was designed to monitor the existence of fungi and yeast in broiler chicks dropping and their environment. The sensitivity pattern of isolated fungi and yeast to various antifungal agents, Terminator disinfectant, and nano copper oxide (CuO NPs) were assessed. The lethal effect (\%) of novel nano-fungicide (Terminator/CuO NPs) to resistant fungi and yeast were evaluated to achieve an efficient control strategy in poultry sectors in the investigated area.

\section{MATERIALS AND METHODS}

\section{Ethical Statement}

The study protocol was approved by the Institutional Animal Care and Use Committee (IACUC) and Institutional Review Board (IRB), reference number [IORG-0009255] of Beni-Suef University.

\section{Study Area}

The study was carried out on four private small commercial poultry farms during the period from August to December 2019 in Beni-Suef (coordinates: 29 $04^{\prime} \mathrm{N}-31^{\circ} 05^{\prime}$ E) province, Egypt. Each farm contained three building units. Broiler chickens were reared in a deep litter system and kept on wood shaving litter. The level of hygienic measures was fair in the investigated farms, whereas the average environmental conditions including in-door temperature $\left(35.5 \pm 0.21^{\circ} \mathrm{C}\right)$, relative humidity $(65.3 \pm 3.5 \%)$, and the speed of airflow $(0.31 \pm 0.2$ $\mathrm{Knots} / \mathrm{h}$ ) were recorded in all investigated buildings during this study.

\section{Samples Collection and Preparation}

Samples were collected randomized from broiler chicks dropping and their environment $(n=320)$. Sampling sites included chicks dropping $(n=50)$, air $(n=40)$, water source (Tap water $n=40)$, feeds $(n=40)$, drinkers $(n=40)$, feeders $(n=40)$, litter $(n=40)$, as well attendants hand swabs $(n=30)$ were obtained from investigating farm workers who were close to chicken flocks. Samples were kept in sterilized screw-capped bottles and bags. Feeds, chicks' litter, and droppings samples were prepared (10 $\mathrm{g}$ from each sample was diluted in $100 \mathrm{~mL}$ sterilized distilled water) and agitated well for
$30 \mathrm{~min}$ at $1000 \mathrm{rpm}$. Air samples were collected at the one-meter height of chicks' litter onto malt extract agar supplemented with chloramphenicol and gentamycin at 40 and $500 \mu \mathrm{g} / \mathrm{mL}$, respectively, using settle plate method, and after an incubation period, all qualitative and quantitative (colony-forming units; $\mathrm{CFU} / \mathrm{m}^{3}$ ) results were obtained. As well, swabs were collected on a sterile screw-capped tube containing $9 \mathrm{~mL}$ Sabouraud dextrose broth, then labeled and sent to the laboratory in an icebox. All samples were examined directly within $24 \mathrm{~h}$ after sampling to investigate the presence of fungal species as a method described by Barnett \& Hunter (1998); Aliyu et al. (2016).

\section{Fungal Pathogens Isolation and Identification}

From each sample dilution, $0.2 \mathrm{~mL}$ was cultured on Sabouraud dextrose agar (SDA: Oxoid $®$, CM0041, Ltd, UK), and malt extract agar supplemented with chloramphenicol and gentamycin at 40, and $500 \mu \mathrm{g} /$ $\mathrm{mL}$, respectively using a spread plate technique (Davis et al., 1990). Thereafter, all cultured fungal pathogens are incubated at $25^{\circ} \mathrm{C}$ for 5-7 days. Fungal isolates were identified based on macroscopic and microscopic features of the isolates obtained from pure cultures using lactophenol blue staining (De Hoog et al., 2000). The features involved shape, color, size, rapidity of growth, and septation of hyphae (Barnett \& Hunter 1998). Isolated fungi were sub-cultured onto SDA slants, incubated at $25^{\circ} \mathrm{C}$ for 5-7 days, then stored in a refrigerator for further mycological studies (Saleemi et al., 2010).

\section{Susceptibility of Fungal Isolates to Antifungal Agents}

Susceptibilities of 65 strains of fungal pathogens [A. niger $(n=13)$, A. fumigatus $(n=13)$, A. terreus $(n=13), P$. corylophilum $(n=13)$, and C. albicans $(n=13)]$ to common antifungal drugs used (Hi-Media Laboratories Pvt. Ltd. A-516, India): Itraconazole (30 mcg), fluconazole (10 mcg), amphotericin-B (100 units), nystatin (100 units), and voriconazole $(1 \mathrm{mcg})$ were evaluated using disc diffusion method. The fungal colonies were suspended in $5 \mathrm{~mL}$ of $0.85 \%$ sterile saline, and the turbidity was adjusted using 0.5 McFarland standard. A swab from the suspension of the inoculum was streaked onto Muller-Hinton agar supplemented with 2\% Glucose and $0.5 \mathrm{mcg} / \mathrm{mL}$ methylene blue dye, then left for $3 \mathrm{~min}$. Antifungal disks were applied to the surface of the inoculated plates. The plates, in an inverted position, were incubated at $30^{\circ} \mathrm{C}$ for $24-48 \mathrm{~h}$ for fungal growth. The inhibition zone was measured and recorded. The obtained results were interpreted according to CLSI (2009).

\section{Antifungal Activity of Terminator and Nanocomposites In-Vitro}

Efficacy of Terminator disinfectant (Coco-benzyldimethyl ammonium chlorides (QAC) 10\% and Glutaraldehyde 15\%, Bomac Laboratories Ltd, New Zealand) at concentrations of (1:200, 1:100, and 1:50 mL), $\mathrm{CuO}$ NPs $(0.5,1.0$, and $2.0 \mathrm{mg} / \mathrm{mL})$, and Terminator/CuO NPs composite $(0.25$, and $0.5 \mathrm{mg} / \mathrm{mL})$ against 65 strains 
of different fungal isolates from chicks dropping and their environment were evaluated using broth microdilution method and disc diffusion assay as the methods described by CLSI $(2008 ; 2009)$ and Amiri et al. (2017).

\section{Preparation of Testing Compounds}

The solutions of the Terminator disinfectant were serially diluted with distilled water to obtain the required concentrations: 1:50, 1:100, and 1:200 mL. Whilst $\mathrm{CuO}$ NPs were synthesized using the chemical precipitation method as described by Phiwdanga et al. (2013). One hundred $\mathrm{mM}$ copper (II) sulfate pentahydrate (CuSO4 5H2O) was dissolved in $50 \mathrm{~mL}$ of distilled water with continuous stirring on a magnetic stirrer for $30 \mathrm{~min}$ at room temperature. Moreover, a solution of $\mathrm{NaOH}$ $(100 \mathrm{mM})$ was added dropwise into the CuSO4 solution with continuous high-speed stirring. The resultant precipitate was washed with deionized water and ethanol $70 \%$. Thereafter, it was centrifugated at $6000 \mathrm{rpm}$ for $15 \mathrm{~min}$ then dried in a hot air oven at $60^{\circ} \mathrm{C}$ for $24 \mathrm{~h}$, followed by calcination at $400^{\circ} \mathrm{C}$ for $4 \mathrm{~h}$. The test solutions of $\mathrm{CuO}$ NPs were $0.5,1.0$, and $2.0 \mathrm{mg} / \mathrm{mL}$. Thereafter, to prepare Terminator/CuO NPs composite, $1 \mathrm{~mL}$ of Terminator disinfectant was dissolved in $100 \mathrm{~mL}$ of distilled water to obtain $(1: 100 \mathrm{~mL})$ then added to $\mathrm{CuO}$ NPs concentrations $(0.25$, and $0.5 \mathrm{mg} / \mathrm{mL})$. The mixture was shaken and stirred well using the magnetic stirrer to avoid agglomeration and the settlement of nanoparticles over the incubation period $(4 \mathrm{~h})$. Thereafter, it was sonicated for $30 \mathrm{~min}$. The nano-solution was heated in a water bath at $40-90^{\circ} \mathrm{C}$ for $2.5 \mathrm{~h}$, then filtered and washed several times with distilled water then, dried in a hot air oven at $50^{\circ} \mathrm{C}$ for $1 \mathrm{~h}$.

\section{Characterization of Testing Nanocomposites}

Nanomaterials ( $\mathrm{CuO}$ NPs and Terminator/CuO NPs) were characterized using high-resolution transmission electron microscopy (HR-TEM, JEOL-JEM 2100) and Fourier-transform infrared spectrum (FT-IR, VERTEX 70) were used to examine the nanomaterials microstructures and description of solid morphologies, respectively (Figures 1 and 2).

\section{Broth Microdilution Assay}

One microliter of fungal strains $\left(1 \times 10^{6}\right)$ colonyforming units $(\mathrm{CFU} / \mathrm{mL})$ was inoculated with different concentrations of Terminator disinfectant (1:50, 1:100, and 1:200 mL), CuO NPs $(0.5,1.0$, and $2.0 \mathrm{mg} / \mathrm{mL})$, and Terminator/CuO NPs $(0.25$, and $0.5 \mathrm{mg} / \mathrm{mL})$ in Sabouraud dextrose broth onto a 96-well plate (Sarstedt, Nümbrecht, Germany) using broth micro-dilution assay according to CLSI (2008) and Amiri et al. (2017). Furthermore, $1 \mu \mathrm{l}$ of broth culture added to Sabouraud dextrose broth without testing compounds served as negative control while testing nanocomposites in Sabouraud dextrose broth (positive control). All treatments and control were incubated at $25-28^{\circ} \mathrm{C}$ for $48 \mathrm{~h}$. The trial was carried out in a triplicate. To determine the minimum inhibitory concentration (MIC) of disin- fectant and nanocomposites, one loopful of each well was streaked on Saparoud dextrose agar supplemented with chloramphenicol and gentamycin at 40 and $500 \mu \mathrm{g} /$ $\mathrm{mL}$, respectively, using the spread plate technique to detect the fungal colony growth at different concentrations of Terminator, $\mathrm{CuO}$ NPs, and Terminator/CuO NPs composite. Meanwhile, the minimum fungicide concentration (MFC) detected the least concentration of Terminator disinfectant and tested nanocomposites indicating the absence of fungal growth $(\mathrm{CFU} / \mathrm{mL})$.

\section{Disc Diffusion Assay}

One hundred discs of a standard size of filter paper (13 $\mathrm{mm}$ diameter) were obtained then saved in screws capped bottles and to ensure sterilization. Bottles were placed in a hot air oven at $180^{\circ} \mathrm{C}$ for $20 \mathrm{~min}$. Sterilized discs were impregnated overnight with the different tested concentrations of Terminator (1:50, 1:100, and 1:200 $\mathrm{mL}$ ) according to recommended concentrations of product meanwhile, $\mathrm{CuO}$ NPs $(0.5,1.0$, and $2.0 \mathrm{mg} /$ $\mathrm{mL})$, and Terminator/ CuO NPs concentrations ( 0.25 and $0.5 \mathrm{mg} / \mathrm{mL}$ ) were chosen as preliminary study. Fungal isolates were diluted in normal saline at a concentration of $10^{6}(\mathrm{CFU} / \mathrm{mL})$, according to reference to McFarland 0.5 . Thereafter, $100 \mu \mathrm{L}$ of a suspension was streaked on Muller-Hinton agar supplemented with 2\% Glucose and $0.5 \mathrm{mcg} / \mathrm{mL}$ methylene blue dye, then left for $3 \mathrm{~min}$. Impregnated discs were placed with sterilized forceps on agar plates. All plates were inculcated at $28^{\circ} \mathrm{C}$ for 48 $\mathrm{h}$ then the diameter of growth inhibition zones around each disc of all tested fungus was measured by caliper and recorded. The readings were taken in a triplicate. This procedure was done according to CLSI (2009) and Amiri et al. (2017).

\section{Statistical Analyses}

Collected data were assembled in Microsoft Excel Spreadsheets, then analyzed using SPSS version 26 (Statistical Package for Social Sciences Software). The prevalence of fungal pathogens in chicks' dropping, its distribution in their environment, and antifungal activity of Terminator disinfectant and novel nano-fungicide composite were statistically analyzed by Chi-Square Test (non-parametric test). To detect the inhibition zone diameter of testing compounds against isolated fungi, the One-Way ANOVA test was applied.

\section{RESULTS}

\section{The Existence of Different Fungal Pathogens in Poultry Flocks and Their Environment}

The prevalence of fungal pathogens in the investigated small commercial poultry flocks was $52.8 \%$ (169/320). The highest prevalence of fungus in chicks' droppings was $56.0 \mathrm{CFU} / \mathrm{g}$ (28/50), followed by their environment and attendants hand swabs (55.8\%; 134/240 and $23.3 \% ; 7 / 30$, respectively) (Table 1 ). Oppositely, the highest prevalence of fungal pathogen isolates, $A$. niger, C. albicans, $A$. fumigatus, $A$. terreus, and $P$. corylophilum 
were $26.6 \%$ (45/169), 22.5\% (38/169), 20.7\% (35/169), $14.8 \%(25 / 169)$, and $15.4 \%(26 / 169)$, respectively at $\chi^{2}=$ $14.7, P<0.05$.

The frequency (\%) of fungal pathogens in examined samples revealed that the highest rate of fungal isolates was detected in chicks' litter and fecal droppings followed by drinkers, feeders, air, and feeds (80.0 CFU/g; 32/40, 56.0 CFU/g; 28/50, 60.0\%; 24/40, 60.0; 24/40, 55.5 $\mathrm{CFU} / \mathrm{m}^{3} ; 22 / 40$, and $45.0 \mathrm{CFU} / \mathrm{g} ; 18 / 40$, respectively) at $\chi^{2}=19.62, \mathrm{p}<0.05$ (Table 2). Furthermore, A. niger was detected in the highest percentage in chicks dropping (35.7 CFU/g; 10/28) followed by feeds, feeder swabs, and chicks' litter (33.3 CFU/g; 6/18, 33.3\%; 8/24, and $31.2 \mathrm{CFU} / g$; 10/32, respectively). Meanwhile, the rate in air samples and drinkers' swabs was $18.2 \mathrm{CFU} / \mathrm{m}^{3} ; 4 / 22$ and $16.7 \% ; 4 / 24$ compared to the least rate recorded in tap water and attendants hand swabs (14.3\%; 2/14 each). In contrast, $A$. fumigatus distribution in air samples and feeds was detected in the highest rate $\left(36.4 \mathrm{CFU} / \mathrm{m}^{3}\right.$; 8/22 and 33.3 CFU/g; 6/18) followed by chicks dropping and their litter (21.4 CFU/g; 6/28 and $18.7 \mathrm{CFU/g;} \mathrm{6/32)}$ respectively. In addition, other $A$. terreus was found at a higher rate $(42.8 \% ; 6 / 14)$ in tap water than other environmental samples. Oppositely, P. corylophilum was not detected in tap water $(0.0 \%)$. Meanwhile, the highest rate was found in air, feeder, and feeds $\left(27.3 \mathrm{CFU} / \mathrm{m}^{3}\right.$; 6/22, 25.0\%; 6/24, and $22.2 \mathrm{CFU/g;} \mathrm{4/18,} \mathrm{respectively).} \mathrm{C.}$ albicans yeast was discovered at the highest rate in attendants hand swabs and tap water $(54.1 \% ; 4 / 7$, and $42.8 \%$;
6/14) compared to drinkers and litter $(33.3 \%$; 8/24, and 25.0 CFU/g; 8/32, respectively) (Table 2 ).

\section{Susceptibility of Fungal Pathogens to Antifungal Agents In Vitro}

Susceptibility testing of fungal isolates to antifungal agents in vitro revealed that all isolated fungus and yeast were highly resistant to voriconazole antifungal drugs except A. fumigatus. Moreover, the susceptibility of both $A$. terreus and $P$. corylophilum were $0.0 \%$ to fluconazole, and amphotericin-B. On the other hand, all fungal isolates clarified the susceptibility to itraconazole drug (100\%). Furthermore, the susceptibility of all Aspergillus spp. (A. niger, A. fumigatus, and A. terreus) to fluconazole was $0.0 \%$. A niger was highly resistant to nystatin $(100.0 \%)$ on contrary the other fungal species were highly susceptible (Table 3).

\section{Characterization of Testing Nanocomposites}

Nanomaterials ( $\mathrm{CuO}$ NPs and Terminator/CuO NPs) were characterized by HR-TEM (Figure 1). It was evident that HR-TEM micrographs of CuO NPs (Figure 1a) showing spherical uniformly NPs distribution in the field. Moreover, the NP size was ranged from 1.39 to $12.5 \mathrm{~nm}$ in diameter (Figure 1b). HR-TEM micrographs of Terminator/CuO NPs clarified the nanoparticles' distribution in nanocomposite (Figure 1c) as NPs appeared

Table 1. Prevalence rate of fungal pathogens in chicks fecal dropping and their environment

\begin{tabular}{lccccccc}
\hline \multirow{2}{*}{$\begin{array}{l}\text { Collected } \\
\text { samples }\end{array}$} & \multicolumn{2}{c}{ Total } & \multicolumn{4}{c}{ Prevalence rate of fungal pathogens No. (\%) } \\
\cline { 2 - 6 } & $\begin{array}{c}\text { Examined } \\
\text { (No.) }\end{array}$ & $\begin{array}{c}\text { Positive } \\
\text { No. }(\%)\end{array}$ & $\begin{array}{c}\text { Aspergillus } \\
\text { niger }\end{array}$ & $\begin{array}{c}\text { Aspergillus } \\
\text { fumigatus }\end{array}$ & $\begin{array}{c}\text { Aspergillus } \\
\text { terreus }\end{array}$ & $\begin{array}{c}\text { Penicillium } \\
\text { corylophilum }\end{array}$ & $\begin{array}{l}\text { Candida } \\
\text { albicans }\end{array}$ \\
\hline Chicks fecal dropping & 50 & $28(56.0)$ & $10(35.7)$ & $6(21.4)$ & $4(14.3)$ & $2(7.1)$ & $6(21.4)$ \\
Environment & 240 & $134(55.8)$ & $34(25.4)$ & $28(20.9)$ & $20(14.9)$ & $24(17.9)$ & $28(20.9)$ \\
Workers hand swabs & 30 & $7(23.3)$ & $1(14.3)$ & $1(14.3)$ & $1(14.3)$ & $0(0.0)$ & $4(54.1)$ \\
Total & 320 & $169(52.8)$ & $45(26.6)$ & $35(20.7)$ & $25(14.8)$ & $26(15.4)$ & $38(22.5)$ \\
\hline
\end{tabular}

Note: The association between the prevalence rate of different fungal pathogens is statistically significant at $\chi 2=14.7(\mathrm{p}<0.05)$.

Table 2. Frequency (\%) of fungal pathogens in different examined samples during study periods

\begin{tabular}{|c|c|c|c|c|c|c|c|}
\hline \multirow{3}{*}{$\begin{array}{l}\text { Collected } \\
\text { samples }\end{array}$} & \multirow{2}{*}{\multicolumn{2}{|c|}{ Total }} & \multicolumn{5}{|c|}{ Prevalence rate of fungal pathogens No. (\%) } \\
\hline & & & \multicolumn{3}{|c|}{ Aspergillus spp. } & \multirow{2}{*}{$\begin{array}{l}\text { Penicillium } \\
\text { corylophilum }\end{array}$} & \multirow{2}{*}{$\begin{array}{l}\text { Candida } \\
\text { albicans }\end{array}$} \\
\hline & $\begin{array}{c}\text { Examined } \\
(\text { No. })\end{array}$ & $\begin{array}{l}\text { Positive } \\
\text { No. }(\%)\end{array}$ & $\begin{array}{c}\text { Aspergillus } \\
\text { niger }\end{array}$ & $\begin{array}{l}\text { Aspergillus } \\
\text { fumigatus }\end{array}$ & $\begin{array}{c}\text { Aspergillus } \\
\text { terreus }\end{array}$ & & \\
\hline Chicks fecal dropping & 50 & $28(56.0)$ & $10(35.7)$ & $6(21.4)$ & $4(14.3)$ & $2(7.1)$ & $6(21.4)$ \\
\hline Air & 40 & $22(55.0)$ & $4(18.2)$ & $8(36.4)$ & $2(9.1)$ & $6(27.3)$ & $2(9.1)$ \\
\hline Tap water & 40 & $14(35.0)$ & $2(14.3)$ & $0(0.0)$ & $6(42.8)$ & $0(0.0)$ & $6(42.8)$ \\
\hline Feeds & 40 & $18(45.0)$ & $6(33.3)$ & $6(33.3)$ & $2(11.1)$ & $4(22.2)$ & $0(0.0)$ \\
\hline Litter & 40 & $32(80.0)$ & $10(31.2)$ & $6(18.7)$ & $4(12.5)$ & $4(12.5)$ & $8(25.0)$ \\
\hline Drinkers & 40 & $24(60.0)$ & $4(16.7)$ & $4(16.7)$ & $4(16.7)$ & $4(16.7)$ & $8(33.3)$ \\
\hline Feeders & 40 & $24(60.0)$ & $8(33.3)$ & $4(16.7)$ & $2(8.3)$ & $6(25.0)$ & $4(16.7)$ \\
\hline Workers hand swabs & 30 & $7(23.3)$ & $1(14.3)$ & $1(14.3)$ & $1(14.3)$ & $0(0.0)$ & $4(54.1)$ \\
\hline Total & 320 & $169(52.8)$ & $45(26.6)$ & $35(20.7)$ & $25(14.8)$ & $26(15.4)$ & $38(22.5)$ \\
\hline
\end{tabular}

Note: The association between frequency of different fungal isolates in investigated data is statistically significant at $\chi 2=19.62(\mathrm{p}<0.05)$. 
Table 3. In vitro susceptibility testing of fungal isolates to antifungal agents

\begin{tabular}{|c|c|c|c|c|c|c|c|c|c|c|c|}
\hline \multirow{4}{*}{$\begin{array}{l}\text { Antifungal } \\
\text { agents }\end{array}$} & \multirow{4}{*}{$\begin{array}{l}\text { Tested } \\
\text { conc. } \\
\text { (mcg/disc) }\end{array}$} & \multicolumn{9}{|c|}{ Susceptibility of fungal isolates (\%) } & \\
\hline & & \multicolumn{6}{|c|}{ Aspergillus spp. } & \multirow{2}{*}{\multicolumn{2}{|c|}{$\begin{array}{l}\text { Penicillium } \\
\text { corylophilum }\end{array}$}} & \multirow{2}{*}{\multicolumn{2}{|c|}{ Candida albicans }} \\
\hline & & \multicolumn{2}{|c|}{ Aspergillus niger } & \multicolumn{2}{|c|}{ Aspergillus fumigatus } & \multicolumn{2}{|c|}{ Aspergillus terreus } & & & & \\
\hline & & S & $\mathrm{R}$ & S & $\mathrm{R}$ & S & $\mathrm{R}$ & S & $\mathrm{R}$ & $S$ & $\mathrm{R}$ \\
\hline IT & 30 & 100.0 & 0.0 & 100.0 & 0.0 & 100.0 & 0.0 & 100.0 & 0.0 & 100.0 & 0.0 \\
\hline FLC & 10 & 0.0 & 100.0 & 0.0 & 100.0 & 0.0 & 100.0 & 0.0 & 100.0 & 100.0 & 0.0 \\
\hline $\mathrm{AP}$ & 100 & 100.0 & 0.0 & 100.0 & 0.0 & 0.0 & 100.0 & 0.0 & 100.0 & 100.0 & 0.0 \\
\hline NS & 100 & 0.0 & 100.0 & 100.0 & 0.0 & 100.0 & 0.0 & 100.0 & 0.0 & 100.0 & 0.0 \\
\hline VRC & 1.0 & 0.0 & 100.0 & 100.0 & 0.0 & 0.0 & 100.0 & 0.0 & 100.0 & 0.0 & 100.0 \\
\hline
\end{tabular}

Note: $\mathrm{S}=$ Susceptible (absence of fungal growth) on agar plates; $\mathrm{R}=$ resistant (presence of fungal growth) on agar plates; IT= Itraconazole; FLC= Fluconazole; $\mathrm{AP}=$ Amphotericin-B; NS= Nystatin; VRC= Voriconazole.
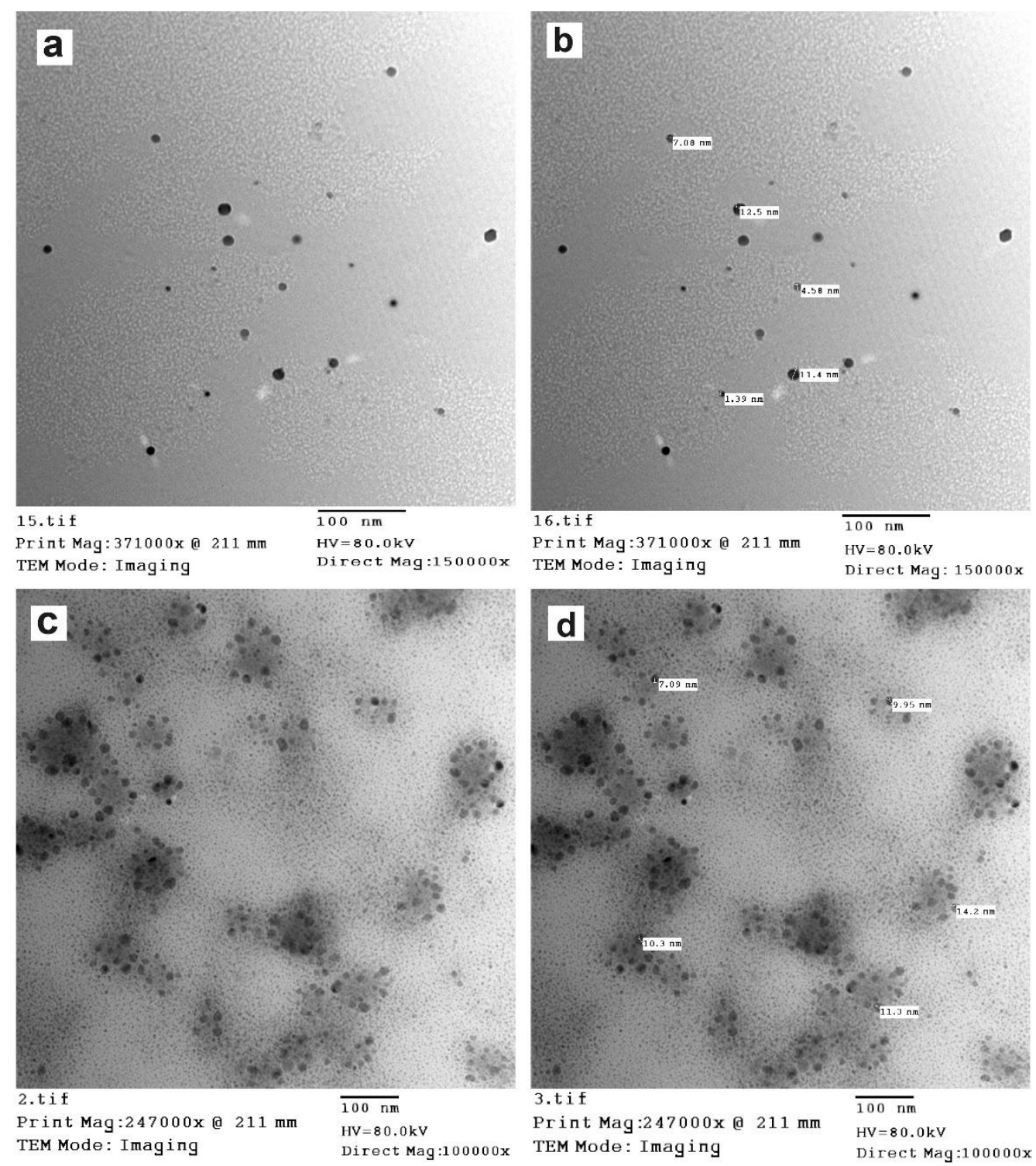

Figure 1. HR-TEM micrographs of CuO NPs (a) clarified morphological spherical uniformly shape of NPs distribution besides the diameter of NPs size (b) was ranged from 1.39 and $12.5 \mathrm{~nm}$. Whilst Terminator/CuO NPs Micrographs (c) clarified irregular spherical and elongated shape of NPs. Nanoparticles size exhibited variation in its diameter (d) ranged up to $14.2 \mathrm{~nm}$. 
in irregular spherical and elongated shapes. Oppositely, NPs diameter varied in size (Figure 1d) ranged up to $14.2 \mathrm{~nm}$. FT-IR spectroscopy of nano copper oxide was obtained in the wavelength range between 500 to 3500 $\mathrm{cm}^{-1}$ (Figure 2a). The intensity of absorption peaks appeared in the range of 3417 to $521 \mathrm{~cm}^{-1}$. Furthermore, the absorption band at $3417 \mathrm{~cm}^{-1}$ corresponded to hydroxyl groups $(\mathrm{O}-\mathrm{H})$, whilst the band at $2379 \mathrm{~cm}^{-1}$ represented $\mathrm{C}-\mathrm{H}$ stretching of an aromatic compound. In addition, the FT-IR spectra of Terminator disinfectant (Figure $2 b)$ revealed a strong absorption peak at $3331 \mathrm{~cm}^{-1}$ that attributed to the absorption of methyl groups in the testing disinfectant. As well, there were characteristic peaks that appeared at 2943, 2539, 2349, 1640, 1361, 1147, and $606 \mathrm{~cm}^{-1}$, respectively. Otherwise, Terminator/CuO NPs (nano-fungicide composite) showed the strongest peak was moving at $3288 \mathrm{~cm}^{-1}$ (Figure 2c), indicating the strong interaction between nano copper oxide and both hydroxyl and methyl groups. Furthermore, there were intense peaks observed at 2431, 2350, 1638, 1477, 1151, and $603 \mathrm{~cm}^{-1}$ that proved the biosynthesis of the nanofungicide composite.
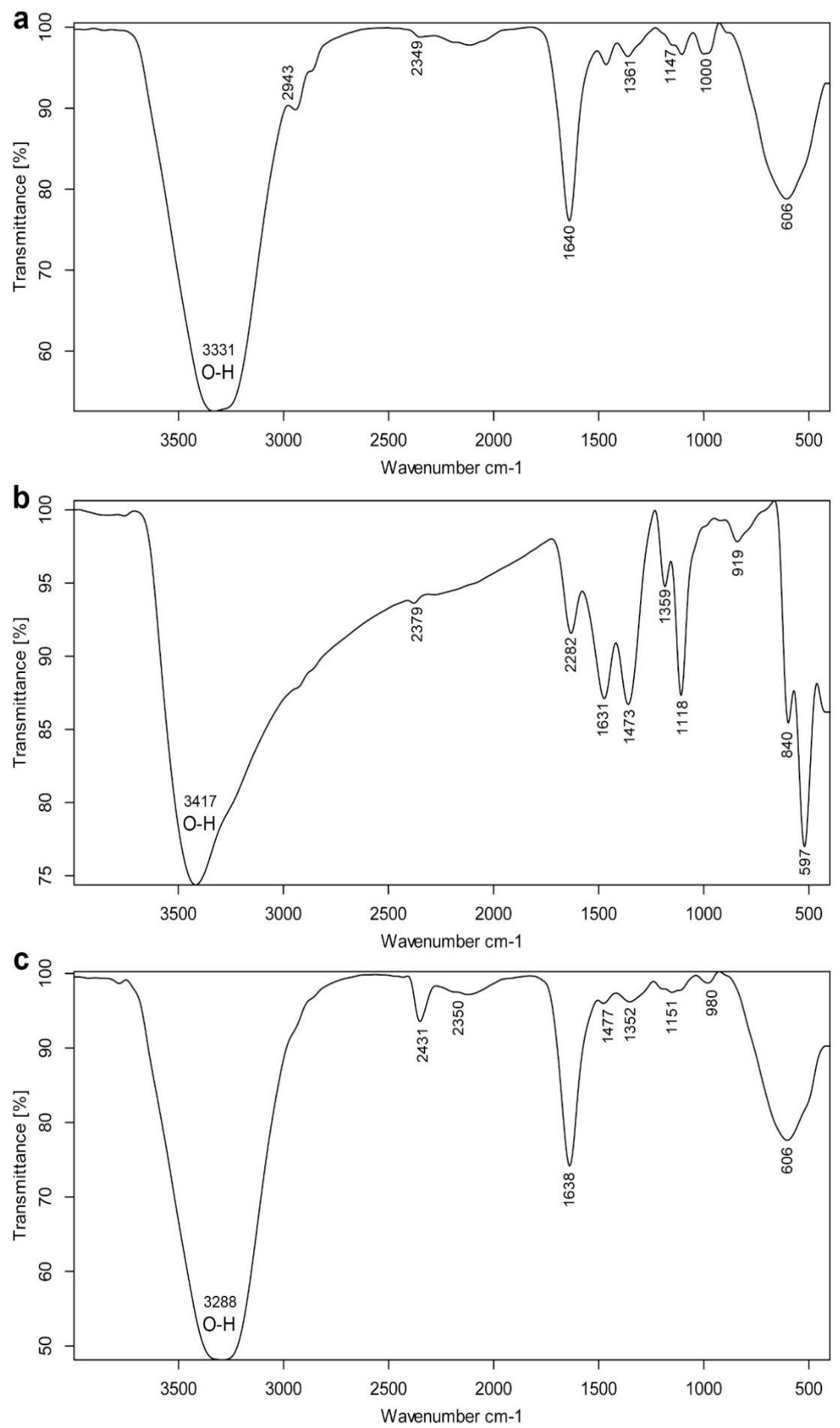

Figure 2. FT-IR spectroscopy of Terminator disinfectant (a), CuO NPs (b), and Terminator/CuO NPs composite (c). 


\section{Antifungal Activity of Terminator Disinfectant and Nanocomposites}

The MIC value of Terminator disinfectant against all isolated fungus and yeast (A. niger, A. fumigatus, $P$. corylophilum, and $C$. albicans yeast) was $1: 100 \mathrm{~mL}$ except for $A$. terreus fungus was $1: 50 \mathrm{~mL}$. In contrast, the minimum concentration of disinfectant that led to the absence of fungal growth (MFC) of all isolated fungi and yeast was $1: 50 \mathrm{~mL}$ at $\mathrm{p} \leq 0.05$. Furthermore, the inhibition zone was ranged between $17.0 \pm 0.04$ and $22.5 \pm 0.01 \mathrm{~mm}$, respectively. Oppositely, the MIC value of $\mathrm{CuO}$ NPs against $A$. niger, A. fumigatus, $P$. corylophilum fungus was $0.5 \mathrm{mg} / \mathrm{mL}$. Meanwhile, both A. terreus and C. albicans were $1.0 \mathrm{mg} / \mathrm{mL}$. The MFC value of nano copper oxide against fungal isolates was $2.0 \mathrm{mg} / \mathrm{mL}$. In addition, the inhibition zone was ranged from $6.0 \pm 0.08$ to $25.0 \pm 1.5$ $\mathrm{mm}$. This study is the first to determine the MIC and MFC values of Terminator/CuO NPs composite against fungal pathogens. The values of nano-fungicides were $0.25 \mathrm{mg} / \mathrm{mL}$ and $0.5 \mathrm{mg} / \mathrm{mL}$, respectively to all fungal isolates. Moreover, the inhibition zone diameter ranged from $26.0 \pm 0.7$ to $45.0 \pm 2.1 \mathrm{~mm}$ (Table 4 and Figure 3).

The susceptibility pattern of fungal isolates to Terminator, $\mathrm{CuO}$ NPs, and Terminator/CuO NPs. It has been revealed that $P$. corylophilum susceptibility to Terminator was $84.6 \%$, followed by $A$. niger, A. fumigatus, C. albicans (76.9\% each) at 1:50 mL concentration (Table 5). Meanwhile, the susceptibility of $A$. terreus did not exceed $61.5 \%$ compared to other tested concentrations of 1:200 mL and 1:100 mL, respectively. Regarding

Table 4. Distribution of MIC and MFC of terminator disinfectant, and nanocomposites against fungal isolates

\begin{tabular}{|c|c|c|c|c|c|c|}
\hline \multirow{2}{*}{ Tested compounds } & & \multicolumn{3}{|c|}{ Aspergillus spp. } & \multirow{2}{*}{$\begin{array}{l}\text { Penicillium } \\
\text { corylophilum }\end{array}$} & \multirow{2}{*}{$\begin{array}{l}\text { Candida } \\
\text { albicans }\end{array}$} \\
\hline & & Aspergillus niger & $\begin{array}{l}\text { Aspergillus } \\
\text { fumigatus }\end{array}$ & $\begin{array}{c}\text { Aspergillus } \\
\text { terreus }\end{array}$ & & \\
\hline \multirow[t]{2}{*}{ Terminator } & $\mathrm{MIC}(\mathrm{mL})$ & $1: 100$ & $1: 100$ & $1: 50$ & $1: 100$ & $1: 100$ \\
\hline & $\operatorname{MFC}(\mathrm{mL})$ & $1: 50$ & $1: 50$ & $1: 50$ & $1: 50$ & $1: 50$ \\
\hline \multicolumn{2}{|c|}{ Diameter of inhibition zone (mm) } & $20.0 \pm 0.11^{\mathrm{b}}$ & $17.0 \pm 0.04^{\mathrm{ab}}$ & $21.5 \pm 3.0^{\mathrm{a}}$ & $21.5 \pm 0.26^{b}$ & $22.5 \pm 0.01^{b}$ \\
\hline \multirow[t]{2}{*}{$\mathrm{CuO}$ NPs } & $\mathrm{MIC}(\mathrm{mL})$ & 0.5 & 0.5 & 1.0 & 0.5 & 1.0 \\
\hline & $\operatorname{MFC}(\mathrm{mL})$ & 2.0 & 2.0 & 2.0 & 2.0 & 2.0 \\
\hline \multicolumn{2}{|c|}{ Diameter of inhibition zone (mm) } & $12.0 \pm 2.0^{\mathrm{ab}}$ & $25.0 \pm 1.5^{b}$ & $6.0 \pm 0.08^{\mathrm{b}}$ & $23.0 \pm 1.5^{b}$ & $11.0 \pm 0.13^{\mathrm{ab}}$ \\
\hline \multirow[t]{2}{*}{ Terminator/CuO NPs } & $\mathrm{MIC}(\mathrm{mL})$ & 0.25 & 0.25 & 0.25 & 0.25 & 0.25 \\
\hline & $\mathrm{MFC}(\mathrm{mL})$ & 0.5 & 0.5 & 0.25 & 0.5 & 0.25 \\
\hline \multicolumn{2}{|c|}{ Diameter of inhibition zone (mm) } & $30.0 \pm 0.0^{\mathrm{a}}$ & $35.0 \pm 0.5^{\mathrm{a}}$ & $26.0 \pm 0.7^{a}$ & $40.0 \pm 0.03^{\mathrm{a}}$ & $45.0 \pm 2.1^{\mathrm{a}}$ \\
\hline
\end{tabular}

Note: Means in the same column with different superscripts differ significantly ( $\mathrm{x} \leq 0.05)$.
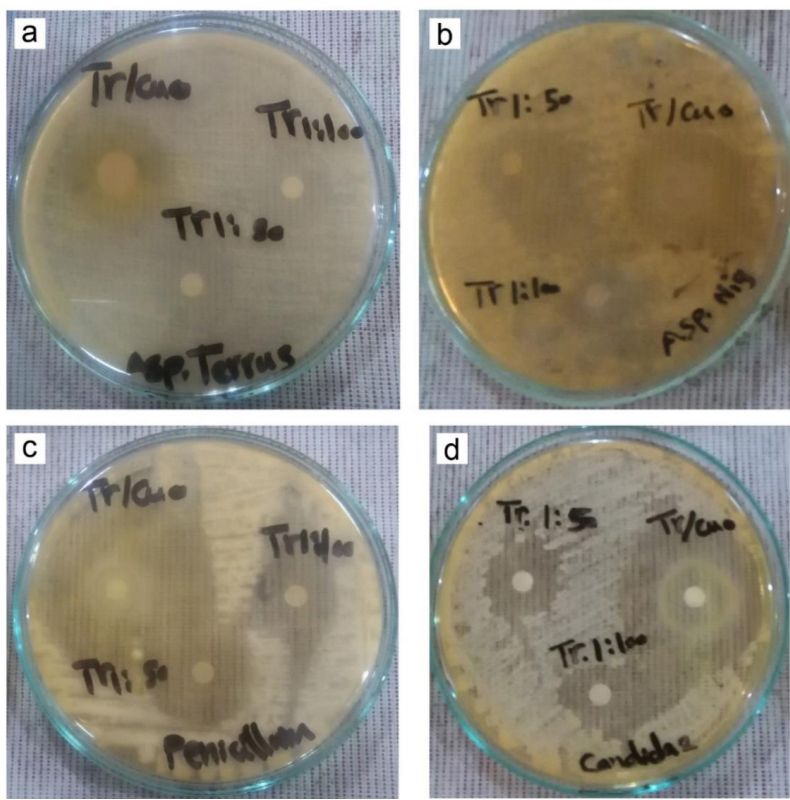

Figure 3. Sensitivity of different fungal pathogens to Terminator disinfectant and nanofungicide composite (Terminator/ CuO NPs) using the disc diffusion assay. The highest sensitivity rate of all Aspergillus spp. [A. terreus (a), and A. niger (b), P. Corylophilum (c), and C. albicans (d)] was found to nano-fungicide composite at $0.5 \mathrm{mg} / \mathrm{mL}$, whereas zone of inhibition was ranged from $26.0 \pm 0.7$ to $45.0 \pm 2.1 \mathrm{~mm}$ compared to testing Terminator disinfectant. 
Table 5. Susceptibility pattern (\%) of fungal pathogens to Terminator, $\mathrm{CuO}$ NPs, and Terminator/CuO NPs composite

\begin{tabular}{|c|c|c|c|c|c|c|c|c|c|c|c|c|}
\hline \multirow{3}{*}{$\begin{array}{l}\text { Tested } \\
\text { compounds }\end{array}$} & & \multicolumn{10}{|c|}{$\begin{array}{l}\text { Susceptibility pattern (\%) of fungal pathogens to disinfectant and nanocomposites. } \\
\text { No. of tested isolates ( } \mathrm{n}=65 \text { strains) }\end{array}$} & \multirow{3}{*}{$\mathrm{p}$-value } \\
\hline & & \multicolumn{2}{|c|}{ Aspergillus niger } & \multicolumn{2}{|c|}{$\begin{array}{l}\text { Aspergillus } \\
\text { fumigatus }\end{array}$} & \multicolumn{2}{|c|}{$\begin{array}{l}\text { Aspergillus } \\
\text { terreus }\end{array}$} & \multicolumn{2}{|c|}{$\begin{array}{l}\text { Penicillium } \\
\text { corylophilum }\end{array}$} & \multicolumn{2}{|c|}{ Candida albicans } & \\
\hline & & $S$ & $\mathrm{R}$ & $S$ & $\mathrm{R}$ & $S$ & $\mathrm{R}$ & $S$ & $\mathrm{R}$ & $S$ & $\mathrm{R}$ & \\
\hline \multirow[t]{3}{*}{ Terminator $(\mathrm{mL})$} & $1: 200$ & 0.0 & 100.0 & 0.0 & 100.0 & 0.0 & 100.0 & 0.0 & 100.0 & 0.0 & 100 & $\mathrm{~N}$ \\
\hline & 1:100 & 69.2 & 30.8 & 61.5 & 38.5 & 46.1 & 35.8 & 76.9 & 23.1 & 69.2 & 30.8 & 0.05 \\
\hline & $1: 50$ & 76.9 & 23.1 & 76.9 & 23.1 & 61.5 & 61.5 & 84.6 & 15.4 & 76.9 & 15.4 & 0.03 \\
\hline \multirow[t]{3}{*}{$\mathrm{CuO}$ NPs } & $0.5 \mathrm{mg} / \mathrm{mL}$ & 15.4 & 84.6 & 23.1 & 76.9 & 0.0 & 100.0 & 15.4 & 84.6 & 0.0 & 100 & 0.01 \\
\hline & $1 \mathrm{mg} / \mathrm{mL}$ & 53.8 & 46.1 & 61.5 & 38.5 & 53.8 & 46.1 & 53.8 & 46.1 & 38.5 & 38.5 & 0.05 \\
\hline & $2 \mathrm{mg} / \mathrm{mL}$ & 69.2 & 30.8 & 76.9 & 23.1 & 61.5 & 38.5 & 69.2 & 30.8 & 61.5 & 38.5 & 0.05 \\
\hline \multirow{2}{*}{$\begin{array}{l}\text { Terminator/ } \\
\text { CuO NPs }\end{array}$} & $0.25 \mathrm{mg} / \mathrm{mL}$ & 92.3 & 7.7 & 84.6 & 18.2 & 100.0 & 0.0 & 92.3 & 7.7 & 100.0 & 0.0 & 0.01 \\
\hline & $0.5 \mathrm{mg} / \mathrm{mL}$ & 100.0 & 0.0 & 100.0 & 0.0 & 100.0 & 0.0 & 100.0 & 0.0 & 100.0 & 0.0 & $\mathrm{~N}$ \\
\hline
\end{tabular}

Note: $\mathrm{S}=$ Susceptible \% (absence of fungal growth) on agar media; $\mathrm{R}=$ resistant (presence of fungal growth) on agar media; $\mathrm{N}=$ means no statistics are computed.

the efficiency of $\mathrm{CuO}$ NPs at a concentration of $2.0 \mathrm{mg} /$ $\mathrm{mL}$ against fungus and yeast isolates clarified that its efficiency wasn't exceeded $76.9 \%$ for A. fumigatus, as well A. niger and $P$. corylophilum (69.2\% each) meanwhile, the sensitivity of $A$. terreus and C. albicans was $61.5 \%$ each compared to the other tested concentrations. Oppositely, the promising nano-fungicide composite (Terminator/ $\mathrm{CuO}$ NPs) exhibited its lethal effect (100\%) against all fungus and yeast isolates at $0.5 \mathrm{mg} / \mathrm{mL}$ compared to its efficiency at $0.25 \mathrm{mg} / \mathrm{mL}$ was significantly high against A. terreus, and C. albicans (100\%) whilst A. niger, P. corylophilum, and A. fumigatus were $92.3 \%, 92.3 \%$, and $84.6 \%$, respectively at $\mathrm{p} \leq 0.01$ (Table 5 ).

\section{DISCUSSION}

The mycotic infection is considered one of the most serious hygienic problems in broiler flocks due to their high morbidity and mortality rate in young chicks that cause immunosuppression and lowering the resistance to various bacterial and viral diseases (Abd El Tawab et al., 2015). Therefore, the current study revealed that the highest prevalence rate of fungal isolates as $A$. niger, A. fumigatus, and C. albicans in a broiler poultry farm. Oppositely, fungal isolates were detected in chicks' litter and chick droppings at the highest rate, followed by drinkers, feeders, air, and feeds, respectively. Increasing fungal infections in chick's environment could be attributed to the increase of environmental contamination with organic materials and sewage, indicating improper hygienic measures and poor ventilation indoor of poultry building. Arne et al. (2011) clarified the most pathogenic fungi affected poultry was $A$. fumigatus that cause brooder's pneumonia as the spores of this fungal species are smaller than another Aspergillus spp. The overriding factors for the flaring of spore dissemination in the air and poultry environment are poor ventilation rate and improper sanitation measures (Gitika et al., 2019). The environmental humidity in the investigated broiler chicken farms was noticed its association with increase the fungal infection during our study period, whereas the average temperature and relative humidity were
$35.5 \pm 0.21^{\circ} \mathrm{C}$, and $65.3 \pm 3.5 \%$, respectively. Furthermore, Kunkle (2003) found both temperature and humidity promoted the rapid growth of fungal hyphae that might be dispersed and inhaled by chickens. In addition, Walker \& White (2017) noticed that environmental and nutritional conditions play a role in reproduce of fungi asexually. The current study was in line with Aliyu et al. (2016), who found that the most prevalent Aspergillus species in poultry feeds were $A$. fumigatus $(58.8 \%)$ followed by $A$. flavus (41.2\%). Oppositely, farmworkers are at great risk of contracting respiratory infection as they are exposed to dust loaded with spores of Aspergillus spp. (A. fumigatus) during their work on a poultry farm. Furthermore, the prevalence of aspergillosis was significantly higher in sawdust litter $(70.0 \%)$ as compared with rice husk litter $(40.0 \%)$ that used in poultry farms (Sabino et al., 2012; Salem \& Ali, 2014) and spreading of those litters in agricultural lands has a potential public health concern, as well toxigenic fungi such as Aspergillus and Penicillium were isolated from poultry litter. Meanwhile, wood shavings litter tended to load higher fungi compared to rice hulls litter (Viegas et al., 2012). Moreover, a huge number of spores are found in wet litter, whereas birds affected by $A$. terreus, and A. niger may show dyspnea, fever, gasping, yellowish diarrhea, and mortality rate ranged from 5\% to $50 \%$ especially during initial 1-3 weeks of age (Dhama et al., 2013). In contrast, Ezekwueche et al. (2018) found that the most predominant Aspergillus spp. was A. niger in poultry dropping samples $(48.0 \%)$. Regarding C. albicans yeast, it was discovered in the highest percentage in attendants hand swabs and tap water compared to drinkers and chicks' litter during this study. Oppositely, Answar et al. (2012) clarified that the high prevalence of C. albicans was reported on the environment. Besides, domestic chicken droppings are a possible reservoir and infection source (72.13\%) compared to soil (27.87\%). So, humans could acquire candidiasis through inhaling spores from chicken droppings (Kemoi et al., 2013).

Developing a control strategy of the toxigenic mycoflora of poultry feeds needs regular monitoring and surveillance of the existence of fungal pathogens 
in their environment (Saleemi et al., 2010; Aliyu et al., 2016). Susceptibility testing of fungal pathogens to antifungal agents should be periodically evaluated to avoid the problem of antifungal resistance patterns. The current study was found that all Aspergillus spp. isolates were completely resistant to both fluconazole and voriconazole antifungal drugs, except $A$. fumigatus fungus. Moreover, $A$. niger revealed a resistance profile to nystatin. As well, the susceptibility of $A$. terreus and $P$. corylophilum were $0.0 \%$ to fluconazole and amphotericinB. Concomitantly, Chowdhary et al. (2014) clarified that Penicillium spp. are among the common fungi worldwide, causing an economic impact as well as various infections in both animals and humans. The same results were reported by Sutton et al. (2004) and Steinbach et al. (2004). In contrast, Wiederhold (2017) found that $A$. fumigatus was resistant to the azole group: voriconazole, itraconazole, and fluconazole, as well as Aspergillus isolates, can cause a high mortality rate. The current study revealed that $C$. albicans was highly sensitive to most of the tested antifungals (itraconazole, fluconazole, amphotericin B, and nystatin) while it exhibited resistance pattern to voriconazole. Flaring up of $C$. albicans occurred when the host immune system became depressed (Kullberg \& Erendurp, 2015; Zaidi et al., 2018).

Prevention and control of aspergillosis in poultry sectors area complicated and difficult problem that depends on maintenance conditions (Ziółkowska \& Tokarzewski, 2006). The current study implicated that the efficiency of Terminator disinfectant was not exceeded by $84.6 \%$ against all isolated fungi and yeasts at the MIC value 1:50 mL. The MIC value of Terminator disinfectant against all isolated fungus and yeast was 1:100 mL. In contrast, the minimum concentration of disinfectant that led to the absence of fungal growth (MFC) of all isolated fungi and yeast was 1:50 mL at $\mathrm{p} \leq 0.05$. Jeffrey (1995) and Howett et al. (1999) showed that quaternary ammonium compounds were low potent against Aspergillus species. On the contrary, Perinelli et al., (2019) revealed that all synthesized quaternary ammonium surfactant compounds were more effective against $C$. albicans yeast.

The lethal effect of nano copper oxide ( $\mathrm{CuO}$ NPs) was not exceeded $76.9 \%$ to all fungal isolates at a concentration of $2.0 \mathrm{mg} / \mathrm{mL}$ with NPs size was ranged from 1.39 to $12.5 \mathrm{~nm}$ in diameter. Furthermore, the FTIR spectra of nano copper oxide clarified the strongest absorption peak at $3417 \mathrm{~cm}^{-1}$ that in line with Ghareib et al. (2019). As well, Khan et al. (2014) pointed to the shape and size of NPs influencing the antifungal activity. Amiri et al. (2017) found that CuO NPs had a weak influence on Candida spp. and it showed a decrease in yeast growth between $30 \%$ to $40 \%$ at $1-1000 \mu \mathrm{g} / \mathrm{mL}$ besides the NPs size was $40 \mathrm{~nm}$ in diameter. In addition, Karimiyan et al. (2015) noticed that the MIC50 value of nano copper oxide for C. albicans was $400 \mu \mathrm{g} / \mathrm{mL}$. In the present work, the conjugation of Terminator disinfectant to $\mathrm{CuO}$ NPs surface was proved through the characterization by HR-TEM and FT-IR spectroscopy. Moreover, the NPs size in nano-fungicide composite ranged from 7.09 to $14.2 \mathrm{~nm}$. As well, characteristic peaks of the nano-fungicide composite were observed at 3288, 2431,
$2350,1638,1477,1151$, and $603 \mathrm{~cm}^{-1}$, respectively, that ensured the biosynthesis of the nanocomposite. In addition, NPs diameter in nano-fungicide varied in size and ranged up to $14.2 \mathrm{~nm}$ that enhanced the penetration power of nanocomposite to the cell wall of all fungal, yeast isolates and destructive or damage it.

\section{CONCLUSION}

Terminator/CuO NPs composite is the future promising nano-fungicide product to eradicate the fungal pathogens from chicken flocks and their environment at a concentration of $0.5 \mathrm{mg} / \mathrm{mL}$. Periodical monitoring of the antifungal efficiency against fungal pathogens is key in detecting and controlling resistant fungus. The novel nano-fungicide compound could be used in a biosecurity program as a strong disinfectant and/or fungicide due to its lethal effect against isolated fungal pathogens.

\section{CONFLICT OF INTEREST}

The authors declare that there is no conflict of interest regarding the publication of this manuscript.

\section{ACKNOWLEDGEMENT}

All Authors are grateful to attendant workers of small commercial poultry farms for their helping us in samples collection.

\section{REFERENCES}

Abd El Tawab, A. A., A. A. A. Maarouf, F. I. El-Hofy, \& K. S. M. Ahmed. 2015. Molecular characterization of some fungi isolated from broiler chicken farms. Benha Vet. Med. J. 29: 106-118.https://doi.org/10.21608/bvmj.2015.31682

Aliyu R. M., M. B. Abubakar, Y. Yakubu, A. B. Kasarawa, N. Lawal, M. B. Bello, \& A. Y. Fardami. 2016. Prevalence of potential toxigenic Aspergillus species isolated from poultry feeds in Sokoto metropolis. Sokoto J. Vet. Sci. 14: 39-44. https://doi.org/10.4314/sokjvs.v14i1.7

Allaker, R. P. 2010. The use of nanoparticles to control oral biofilm formation. J. Dent. Res. 89: 1175-1186. https://doi. org $/ 10.1177 / 0022034510377794$

Amiri, M., Z. Etemadifar, A. Daneshkazemi, \& M. Nateghi. 2017. Antimicrobial effect of copper oxide Nanoparticles on some oral bacteria and candida species. J. Dent. Biomater. 4: 347-352.

Answar, K. P., A. Malik, \& H. K. Subwin. 2012. Profile of candidiasis in HIV infected patients. Iran J. microbiol. 4: 204-209.

Arne, P., S. Thierry, D. Wang, M. Deville, \& G. Le Loch. 2011. Aspergillus fumigatus in poultry. Int. J. Microbiol. 2011: 14. https://doi.org/10.1155/2011/746356

Asfaw, M. \& D. Dawit. 2017. Review on major fungal disease of poultry. Br. J. Poult. Sci. 6: 16-25.

Azarakhsh, Y., A. Sabokbar, \& M. Bayat. 2011. Incidence of the most common toxigenic Aspergillus species in broiler feeds in Kermanshah Province, West of Iran. Glob. Vet. 6: 73-77.

Barnett, H. L. \& B. B. Hunter. 1998. Illustrated Genera of Imperfect Fungi, fourth edition, Minn. Minneapolis Burgnees Publishing Company, Minneapolis M. N. p. 241.

Beemaert, L. A., F. Pasmans, L. Van Waeyenberghe, F. Haesebrouck, \& A. Martel. 2010. Asperigillosis infection in birds: A review. Avian Pathol. 39: 325-331. https://doi.or g/10.1080/03079457.2010.506210 
Brycki, B., I. Kowalczyk, \& A. Kozirog. 2011. Synthesis, molecular structure, spectral properties and antifungal activity of polymethylene- $\alpha$, $\omega$-bis (N, N-dimethylNdodecyloammonium bromides). Molecules 16: 319-335. https://doi.org/10.3390/molecules16010319

Carter, G. R. \& J. R. Cole. 1990. Diagnostic Procedure in Veterinary Bacteriology and Mycology. $5^{\text {th }}$ Ed. Academic Press Inc, USA. p. 372-373.

Chang, Y. N., M. Zhang, L. Xia, J. Zhang, \& G. Xing. 2012. The toxic effects and mechanisms of $\mathrm{CuO}$ and $\mathrm{ZnO}$ nanoparticles. Materials 5: 2850-2871. https://doi.org/10.3390/ ma5122850

Chowdhary, A., S. Kathuria, K. Agarwal, N. Sachdeva, P. K. Singh, S. Jain, \& J. F. Meis. 2014. Voriconazole-resistant Penicillium oxalicum: an emerging pathogen in immunocompromised hosts. Open Forum Infect. Dis. 1: 29. https:// doi.org/10.1093/ofid/ofu029

Cioffi, N. \& M. Rai. 2012. Nano-Antimicrobials: Progress and Prospects. $1^{\text {st }}$ Ed. Springer Berlin Heidelberg, Berlin, Germany. https://doi.org/10.1007/978-3-642-24428-5

Clinical and Laboratory Standards Institute. 2008. Reference Method for Broth Dilution Antifungal Susceptibility Testing of Yeast; Approved Standard-Third Edition. CLSI document M27-A3. Clinical and Laboratory Standards Institute, Wayne.

Clinical and Laboratory Standards Institute. 2009. Method for Antifungal Disk Diffusion Susceptibility Testing of Yeasts; Approved Guideline $2^{\text {nd }}$. Clinical and Laboratory Standards Institute, Wayne.

Davis, B. D., R. Dulbecco, H. N. Eisen, \& H. S. Ginsberg. 1990. Microbiology. Subsequent edition. Lippincott Williams \& Wilkins Publisher, Philadelphia.

De Hoog, C., J. Guarro , G. Gené, \& M. J. Figueiras. 2000. Atlas of Clinical Fungi. $2^{\text {nd }}$ ed. Centraalbureau voor Schimmelcultures, Utrecht.

Dhama, K., S. Chakraborty, A. K. Verma, R. Tiwari , R. Barathidasan , A. Kumar, \& S. D. Singh. 2013. Fungal/ mycotic diseases of poultry-diagnosis, treatment, and control: A review. PJBS 16: 1626-1640. https://doi.org/10.3923/ pjbs.2013.1626.1640

Eshed, M., J. Lellouche, S. Matalon, A. Gedanken, \& E. Banin. 2012. Sonochemical coatings of $\mathrm{ZnO}$ and $\mathrm{CuO}$ nanoparticles inhibit Streptococcus mutans biofilm formation on teeth model. Langmuir 28:12288-12295. https://doi.org/10.1021/ la301432a

Ezekwueche, S. N., C. U. Umedum, C. C. Uba, \& I. F. Anagor. 2018. Fungi isolated from poultry droppings express antagonism against clinical bacteria isolates. Microbiol. Res. J. Intern. 26:1-8. https://doi.org/10.9734/MRJI/2018/46183

Ghareib, M., W. Abdallaha, M. Abu Tahona, \& A. Tallimab. 2019. Biosynthesis of copper oxide nanoparticles using the preformed biomass of Aspergillus fumigatus and their antibacterial and photocatalytic activities. Dig. J. Nanomater. Bios. 14: 291 - 303. https://doi.org/10.1049/mnl.2019.0218

Girma, G., M. Abebaw, M. Zemene, Y. Mamuye, \& G. Getaneh. 2016. A Review on Aspergillosis in Poultry. J. vet. Sci. Technol. 7:1-5. https://doi.org/10.4172/2157-7579.1000382

Gitika, A., R. Mishra, S. K. Panda, C. Mishra, \& P. R. Sahoo. 2019. Evaluation of Antifungal Activity of Curcumin against Aspergillus flavus. Int. J. Curr. Microbiol. App. Sci. 8:2323-2329. https://doi.org/10.20546/ijcmas.2019.807.284

Howett, M. K., E. B. Neely, N. D. Christensen, B. Wigdah, F. C. Krebs, D. Malamud, S. D. Patrick, M. D. Pickel, P. A. Welsh, C. A. Reed, M. G. Ward, L. R. Budgeon, \& J. W. Kreider. 1999. A broad spectrum microbiocide with virucidal activity against sexually transmitted viruses. Antimicrob. Agents Chemother. 43:314-321. https://doi. org/10.1128/AAC.43.2.314

Hyde, K. D., A. M. Al-Hatmi, B. Andersen, T. Boekhout, W.
Buzina, T.L. Dawson, D.C. Eastwood, E.G. Jones, S. de Hoog, Y. Kang, \& J.E. Longcore. 2018. The world's ten most feared fungi. Fungal Divers. 93:161-194. https://doi. org/10.1007/s13225-018-0413-9

Jeffrey, D. J. 1995. Chemicals used as disinfectants: Active ingredients and enhancing additives. Rev. sci. Tech. 14: 57-74. https://doi.org/10.20506/rst.14.1.828

Jennings, M. C., K. P. Minbiole, \& W. M. Wuest. 2015. Quaternary ammonium compounds: An antimicrobial mainstay and platform for innovation to address bacterial resistance. ACS. Infect. Dis. 1: 288-303. https://doi. org/10.1021/acsinfecdis.5b00047

Karimiyan, A., H. Najafzadeh, M. Ghorbanpour, \& S. Hekmatimoghaddam. 2015. Antifungal effect of magnesium oxide, zinc oxide, silicon oxide and copper oxide nanoparticles against Candida albicans. Zahedan J. Res. Med. Sci. 17: 29-31. https://doi.org/10.17795/zjrms-2179

Kemoi, E. K., P. Okemo, \& C. C. Bii. 2013. Isolation of candida species in domestic chicken (Gallus gallus) droppings in Kabigeriet village, Nakuru county Kenya. Eur. Sci. J. 9:309-318

Khan, M. F., M. Hameedullah, A. H. Ansari, E. Ahmad, M. B. Lohani, R. H. Khan, M. M. Alam, W. Khan, F. M. Husain, \& I. Ahmad. 2014. Flower-shaped $\mathrm{ZnO}$ nanoparticles synthesized by a novel approach at near-room temperatures with antibacterial and antifungal properties. Int. J. Nanomedicine. 9: 853-864. https://doi.org/10.2147/IJN. S47351

Khosravi,A.R., H.Shokri, T.Ziglari,A.R. Naeini, Z. Mousavi, \& H. Hashemi. 2008. Outbreak of severe disseminated aspergillosis in a flock of ostrich (Struthio camelus). Mycoses. 51: 557-559. https://doi.org/10.1111/j.1439-0507.2008.01504.x

Kullberg, B. J. \& M. C. Arendrup. 2015. "Invasive candidiasis". N. Engl. J. Med. 373: 1445-56. https://doi.org/10.1056/ NEJMra1315399

Kunkle, R. A. 2003. Aspergillosis. In: Saif Y. M., H. J. Barnes, J. R. Glisson, A. M. Fadly, L. R. Mc Dougald, \& D. E. Swayne (Eds). Diseases of Poultry. $11^{\text {th }}$ edition. Iowa State University Press, Ames. p. 883-895.

Lara, H. H., D. G. Romero-Urbina, C. Pierce, J. L. Lopez-Ribot, M. J. Arellano-Jiménez, \& M. Jose-Yacaman. 2015. Effect of silver nanoparticles on Candida albicans biofilms: An ultrastructural study. J. Nanobiotechnol. 13:91. https://doi. org/10.1186/s12951-015-0147-8

Marek J., D. Malinak, R. Dolezal, O. Soukup, M. Pasdiorova, M. Dolezal \& K. Kuca. 2015. Synthesis and disinfection effect of the pyridine-4-aldoxime based salts. Molecules 20: 3681-3696. https://doi.org/10.3390/molecules20033681

Misuzu, K., P. Chesenda, Y. Akra, C. Piphat, C. Toru , S. Petchsri, M. Taiga, K. hiroshi , H. Yasuhito, M. Yushitsuru, I. Yutaka, \& K. Shungeru. 2004. Environmental isolation of Cryptococcus neoformans from an endemic region of HIVassociated cryptococcosis in Thailand. Yeast 21: 809-812. https://doi.org/10.1002/yea.1112

Perinelli, D. R., D. Petrelli, L. A. Vitali, G. Bonacucina, M. Cespi, D. Vllasaliu, G. Giorgioni, \& G. F. Palmieri. 2019. Quaternary ammonium leucine-based surfactants: The effect of a benzyl group on physicochemical properties and antimicrobial activity. Pharmaceutics 11: 287. https://doi. org/10.3390/pharmaceutics11060287

Pernak, J., J. Rogoża, \& I. Mirska. 2001. Synthesis and antimicrobial activities of new pyridinium and benzimidazolium chlorides. Eur. J. Med. Chem. 36: 313-320. https://doi. org/10.1016/S0223-5234(01)01226-0

Phiwdanga, K., S. Suphankija, W. Mekprasarta, \& P. Wisanu. 2013. Synthesis of $\mathrm{CuO}$ nanoparticles by precipitation method using different precursors. Energy Proc. 34: 740-5. https://doi.org/10.1016/j.egypro.2013.06.808

Russell, R. \& M. Peterson. 2007. Aflatoxin contamination in 
chilli from Pakistan. Food Control. 18: 817-820. https://doi. org/10.1016/j.foodcont.2006.04.005

Sabino, R., V. M. Faisca, E. Carolino, C. Verissimo, \& C. Viegas. 2012. Occupational exposure to Aspergillus by swine and poultry farm workers in Portugal J. Toxicol. Env. Heal. A. 75: 1381-1391. https://doi.org/10.1080/15287394.2012.72117 0

Saleemi, M. K., M. Z. Khan, A. Khan, \& I. Javed. 2010. Mycoflora of poultry feeds and mycotoxins producing potential of Aspergillus species. Pak. J. Bot. 42: 427-434.

Salem, L. M. A. \& A. Ali. 2014. Epidemiological study of Aspergillosis in chickens and human contacts in chicken farms at Kalyoubia Governorate. IOSR-JAVS. 7: 20-24. https://doi.org/10.9790/2380-07742024

Steinbach, W. J., D. K. Benjamin, D. P. Jr Kontoyiannis, J. R. Perfect, I. Lutsar, K. A. Marr, M. S. Lionakis, H. A. Torres, H. Jafri, \& T. J. Walsh. 2004. Infections due to Aspergillus terreus: A multicenter retrospective analysis of cases. Clin. Infect. Dis. 39: 192-198. https://doi.org/10.1086/421950
Sutton, D. A., S. E. Sanche, S. G. Revankar, A. Q. Fothergill, \& M.G. Rinaldi. 2004. In vitro amphotericin B resistance in clinical isolates of Aspergillus terreus, a head-to-head comparison of voriconazole. Clin. Infect. Dis. 39: 743-746.

Walker, G. M. \& N. A. White. 2017. In: Kavangh, K. (Ed.), Fungi: Biology and Applications. John Wiley \& Sons, West Sussex, England.

Viegas, C., E. Carolino, J. Malta-Vacas, R. Sabino, S. Viegas, \& C. Veríssimo. 2012. Fungal contamination of poultry litter: A public health problem. J. Toxicol. Env. Heal. A. 75: 13411350. https://doi.org/10.1080/15287394.2012.721165

Wiederhold, N. P. 2017. Antifungal resistance: current trends and future strategies to combat. Infect. Drug Resist. 10:249259. https://doi.org/10.2147/IDR.S124918

Zaidi, K. U., A. Mani, R. Parmar, \& V. Thawani. 2018. Antifungal susceptibility pattern of Candida albicans in human infections. Open Bio. Sci. J. 4: 1-6. https://doi. org/10.2174/2352633501804010001

Ziółkowska, G. \& S. Tokarzewski. 2006. Determination of antifungal activity of Enizol: A specific disinfecting preparation. Med. Weter. 62:792-796. 